\title{
Gastric fluid volume in infants for pyloromyotomy
}

Scott D Cook-Sather MD, Heather V Tulloch MD, Chris A Liacouras MD, ${ }^{*}$ Mark S Schreiner MD

Purpose: To quantify gastric fluid volumes in infants with pyloric stenosis presenting for pyloromyotomy and to demonstrate endoscopically the efficacy of blind aspiration for gastric fluid recovery. We hypothesized that previous diagnostic contrast studies, preoperative nasogastric suction, and fasting interval would not affect these volumes.

Methods: Seventy-five infants scheduled for pyloromyotomy were given atropine before induction of anaesthesia. For those who had undergone preoperative nasogastric suction, the nasogastric tube was aspirated and removed. A $14 \mathrm{~F}$ multiorificed orogastric catheter was blindly passed to aspirate gastric fluid for measurement. Following tracheal intubation, 15/75 subjects underwent gastroscopy to measure residual gastric fluid.

Results: Gastric fluid volume removed by blind aspiration averaged $4.8 \pm 4.3 \mathrm{ml} \mathrm{kg}^{-1}$ with $83 \%$ of patients having $>1.25 \mathrm{ml} / \mathrm{kg}^{-1}$. Atthough 14 of the 15 patients evaluated by endoscope had $s 1 \mathrm{ml}$ residual gastric fluid, one had $1.8 \mathrm{ml} \cdot \mathrm{kg}$. Recovery of total gastric fluid volume by blind aspiration averaged $96 \pm 7 \%$. The large gastric fluid volumes were independent of a history of barium study, preoperative nasogastric suction, and fasting interval.

Conclusion: Infants with pyloric stenosis have large gastric fluid volumes which are not substantially reduced by preoperative nasogastric suction. Blind aspiration of gastric contents prior to induction of anaesthesia provides a reliable estimate of total gastric fluid for most of these infants, although the occasional infant may retain a small amount of gastric fluid. The clinical importance of such a residual volume is uncertain.

Objectif : Quantifier le volume de liquide gastrique chez des enfants porteurs de sténose du pylore se présentant pour une pylorotomie et démontrer par endoscopie l'efficacité de l'aspiration à l'aveugle pour le recueillir. Nous avons supposé que les examens en contraste antérieurs, les aspirations nasogastriques préopératoires et les intervalles de jeûne n'affectaient pas le volume gastrique.

Méthodes : Soixante-quinze enfants programmés pour un pylorotomie ont reçu de l'atropine avant linduction de l'anesthésie. Si une sonde nasogastrique était déjà en place, celle-ci était aspirée et retirée. Une sonde orogastrique $14 \mathrm{~F}$ à orifices multiples était introduite à l'aveugle dans l'estomac dans le but d'aspirer le liquide et de le mesurer. Après l'intubation de la trachée, 15 des sujets sur 75 ont subi un gastroscopie pour évaluer le liquide gastrique résiduel.

Résultats : Le volume moyen de liquide gastrique retiré par l'aspiration à l'aveugle était $4,8 \pm 4,3 \mathrm{ml} / \mathrm{kg}^{-1}$ et dépassait $1,25 \mathrm{ml} \cdot \mathrm{kg}^{-1}$ chez $83 \%$ des patients. Par endoscopie, chez 14 des 15 sujets évalués. le volume résiduel était $\leqslant \mid \mathrm{ml}$; toutefois, il était de $1,8 \mathrm{ml} \cdot \mathrm{kg}^{-1}$ chez un des patients. Le volume de liquide gastrique recueilli par aspiration à l'aveugle était de $96 \pm 7 \%$ du total. Les volumes importants r'étaient pas en relation avec des examens barytés préalables, la succion nasogastrique préopératoire et l'intervalle de jeûne.

Conclusion : Les enfants souffrant de sténose du pylore ont de grands volumes de liquide gastrique qui ne sont pas substantiellement diminués par la succion nasogastrique préopératoire. L'aspiration à l'aveugle du contenu gastrique avant l'induction procure une estimation valide du contenu total de liquide chez la plupart des enfants, bien qu'à loccasion un enfant puisse en retenir une petite quantité. L'importance clinique de ce volume résiduel demeure indéterminée.

From the Department of Anesthesiology and Critical Care Medicine; Division of Gastroenterology and Nutrition,

The Children's Hospital of Philadelphia/University of Pennsylvania, 34th St. and Civic Center Blvd., Philadelphia, PA 19104-4399.

Address correspondence to: Dr. Scott D Cook-Sather.

Accepted for publication November 30, 1996. 
W

ITH an incidence ranging from 2-9: $1000,{ }^{1,2}$ hypertrophic pyloric stenosis is one of the most common gastrointestinal disorders requiring abdominal surgery in infancy., ${ }^{3,4}$ The hypertrophic circular and longitudinal muscularis of the pylorus and distal antrum of the stomach result in gastric outlet obstruction and subsequent non-bilious vomiting. Because of the potential for large gastric fluid volumes (GFVs) due to this outlet obstruction and due to concomitant gastroeosophageal reflux, infants with pyloric stenosis are thought to be at increased risk for vomiting and aspiration at the time of induction of anaesthesia. ${ }^{5-7}$ Evacuation of the stomach contents before induction of anaesthesia has been advocated to reduce this risk, yet claims of complete gastric emptying with an $8 \mathrm{~F}$ nasogastric tube ${ }^{5}$ or even a considerable reduction of gastric contents in the decubitus infant with an 8 to $12 \mathrm{~F}$ red rubber tube ${ }^{7}$ are unsubstantiated. There are, in fact, anecdotal reports of incomplete evacuation, with as much as $30-100 \mathrm{ml}$ remaining after suctioning using a 10 or $12 \mathrm{~F}$ gastric tube. ${ }^{6}$ Therefore, despite blind gastric aspiration attempts prior to induction of anaesthesia, many anaesthetists consider infants with pyloric stenosis to have a full stomach and proceed with awake intubation or intubation following rapid sequence or modified rapid sequence induction.

This study was designed to document the large GFVs in infants with pyloric stenosis presenting for pyloromyotomy and, using endoscopy, to validate the efficacy of our blind aspiration technique for gastric fluid recovery. Our blind aspiration technique derived from historical success in removing large volumes of gastric fluid using $14 \mathrm{~F}$ multiorificed suction catheters and had evolved to include repeated placement based on a previous investigation in older infants and children. In that study we found that blind aspiration of gastric contents would recover $97 \pm 8 \%$ of total GFV provided the technique consisted of three aspirations (with a large sump tube in the supine and left and right lateral decubitus positions. $)^{8}$ We hypothesized that a blind aspiration technique using a large-bore, multiorificed suction catheter passed two to three times into the stomach would effectively remove all gastric fluid in infants with pyloric stenosis. We sought to demonstrate that the GFV frequency distribution generated from these data would reflect much larger GFVs than that of healthy, fasted children presenting for elective surgery. We further hypothesized that these large GFVs would be of such magnitude as to be unaffected by the administration of barium for diagnostic purposes, preoperative nasogastric suction (a clinical impression based on our institutional experience using $\leq 10 \mathrm{~F}$ tubes), and fasting interval (with prediction of GFV complicated by intermittent vomiting on the ward.)

\section{Methods}

After institutional review board approval and with parental informed consent we prospectively studied 75 ASA physical status I and II infants undergoing pyloromyotomy. None of the infants had known abnormalities of the airway or respiratory or cardiovascular systems. All were fasted preoperatively and had undergone iv fluid resuscitation with electrolyte correction. Atropine $\left(20 \mu \mathrm{g} \cdot \mathrm{kg}^{-1} \mathrm{po}\right.$, a volume $<0.5 \mathrm{ml}$ ) was administered $15-30 \mathrm{~min}$ before induction of anaesthesia. Prior to induction, the anaesthetists placed ECG leads and a precordial stethoscope, blood pressure cuff, and pulse oximetry probe. Atropine $\left(20 \mu \mathrm{g} \cdot \mathrm{kg}^{-1}\right.$ iv) was administered if the infant's heart rate was $<150 \mathrm{bpm}$. If a nasogastric tube was present, it was suctioned and removed and the small volumes of fluid obtained were evacuated into the suction canister for inclusion with $\mathrm{GFV}_{\text {blind }}$. Following a brief period of mask oxygenation and with the infant in the supine position, the anaesthetists blindly passed a $14 \mathrm{~F}$ multiorificed orogastric tube (Airlife Oxygen Catheter, Baxter, Valencia, CA) and aspirated the gastric contents using wall suction. The catheter was inserted and removed a total of two to three times, until little or no gastric fluid was obtained. Proper placement was ensured by inserting the catheter to a measured topographic distance, observing the tip tenting the epigastrium, and/or removing gastric contents into the in-line suction canister. The gastric contents were then removed from the suction canister and measured using a calibrated syringe. The anaesthesia housestaff proceeded with an awake intubation using an oxyscope blade, a rapid sequence paralyzed intubation, or a modified rapid sequence intubation. Rapid sequence technique consisted of preoxygenation, cricoid pressure, 5-7 $\mathrm{mg} \cdot \mathrm{kg}^{-1}$ thiopentone, and 2 $\mathrm{mg} \cdot \mathrm{kg}^{-1}$ succinylcholine ip prior to intubation. Modified rapid sequence induction included ventilation through cricoid pressure following 5-7 $\mathrm{mg} \cdot \mathrm{kg}^{-1}$ thiopentone and one of the following iv neuromuscular blocking agents: $0.4-0.5 \mathrm{mg} \cdot \mathrm{kg}^{-1}$ atracurium, $0.6-1.0$ $\mathrm{mg} \cdot \mathrm{kg}^{-1}$ rocuronium, $2 \mathrm{mg} \cdot \mathrm{kg}^{-1}$ succinylcholine, or $0.1-0.2 \mathrm{mg} \cdot \mathrm{kg}^{-1}$ vecuronium.

We recorded each infant's age, weight, race, fasting interval $(0-8,>8-16,>16-24,>24 \mathrm{hr})$ and GFV evacuated by the blind aspiration technique $\left(\mathrm{GFV}_{\text {blind }}\right)$. For three of the 75 patients, GFV $_{\text {blind }}$ was unintentionally left unrecorded and, therefore, not included in the analysis. We also recorded the presence or absence of a preoperative nasogastric tube and whether diagnostic studies for pyloric stenosis had included barium and/or ultrasound. After induction of anaesthesia and tracheal intubation, one of the investigators (CAL), an experienced endoscopist, passed an Olympus GIF-N30 neonatal endoscope into the stomach of 15 infants to 
remove and measure residual GFV $\left(\mathrm{GFV}_{\text {residual }}\right)$. These 15 infants were studied based on specific parental consent (not all parents agreed to this component of the study) and availability of the endoscope. We then calculated the total GFV (GFV total) as $\mathrm{GFV}_{\text {blind }}+\mathrm{GFV}_{\text {residual' }}$.

\section{Statistical Analysis}

Unless otherwise noted, values for age, weight, $\mathrm{GFV}_{\text {blind }}$ and $\mathrm{GFV}_{\text {residual }}$ are reported as mean $\pm S D$. Because GFV is not normally distributed, the data are also reported as median \pm interquartile range (IQR). Interquartile range is the distance between the first quartile (25th percentile) and the third quartile (75th percentile) and provides a measure of dispersion. We defined the recovery of GFV total by blind aspiration as the ratio $\mathrm{GFV}_{\text {blind }} / \mathrm{GFV}_{\text {total }}$ in percent and maintained the integrity of the paired $\mathrm{GFV}_{\text {blind }}$ and $\mathrm{GFV}_{\text {residual }}$ data. Differences in $\mathrm{GFV}_{\text {blind }}$ for patients with or without a nasogastric tube and those given or not given barium were compared using the Mann-Whitney $U$ test. We used a Kruskal-Wallis test to determine whether GFV $_{\text {blind }}$ depended on the fasting interval. A $P$ value $\leq 0.05$ was taken to be significant.

\section{Results}

The demographic data are presented in Table I. Patients averaged five weeks of age at diagnosis and surgery and the male to female ratio was $4.8: 1$. The characteristics of this patient population are similar to that of other reports. ${ }^{1-7}$

The blind aspiration technique yielded large volumes of gastric fluid in infants with pyloric stenosis. The average $\mathrm{GFV}_{\text {blind }}$ was $4.8 \pm 4.3 \mathrm{ml} \cdot \mathrm{kg}^{-1}$ (Table II), with $60 / 72(83 \%)>1.25 \mathrm{ml} \cdot \mathrm{kg}^{-1}$ (Figure 1 ).

TABLE I Demographic Data for All Subjects

\begin{tabular}{ll}
\hline $\mathrm{n}$ & 75 \\
$\mathrm{age}(\mathrm{wk})$ & $5.0 \pm 2.3$ \\
weight $(\mathrm{kg})$ & $3.8 \pm 0.7$ \\
sex $\mathrm{M} / \mathrm{F}$ & $62 / 13$ \\
\hline
\end{tabular}

Values shown for age and weight are mean $\pm S D$.

TABLE II Recovery of Gastric Fluid Volume

\begin{tabular}{|c|c|}
\hline median $\mathrm{GFV}_{\text {blind }} \pm \mathrm{IQR}\left(\mathrm{ml} \cdot \mathrm{kg}^{-1}\right) \mathrm{n}=72$ & $3.4 \pm 4.9$ \\
\hline $\mathrm{GFV}_{\text {blind }}\left(\mathrm{ml} \cdot \mathrm{kg}^{-1}\right) \mathrm{n}=72$ & $4.8 \pm 4.3$ \\
\hline $\mathrm{GFV}_{\text {residual }}\left(\mathrm{ml} \cdot \mathrm{kg}^{-1}\right) \mathrm{n}=15$ & $0.8 \pm 1.8$ \\
\hline $\mathrm{GFV}_{\text {rotal }}^{\text {rest }}\left(\mathrm{ml} \cdot \mathrm{kg}^{-1}\right) \mathrm{n}=15$ & $5.3 \pm 5.0$ \\
\hline Recovcry: GFV ${ }_{\text {blind }} / \mathrm{GFV}_{\text {toral }}(\%) \mathrm{n}=15$ & $96 \pm 7$ \\
\hline
\end{tabular}

$\mathrm{GFV}_{\text {blind }}=$ gastric fluid volume recovered by blind aspiration, $\mathrm{GFV}_{\text {rejidual }}=$ residual gastric fluid volume measured by endoscopy following blind aspiration, $\mathrm{GFV}_{\text {total }}=$ combined $\mathrm{GFV}_{\text {blind }}$ and $\mathrm{GFV}_{\text {residual, }} \mathrm{IQR}=$ interquartile range. Unless otherwise indicated, values shown are mean $\pm S D$.

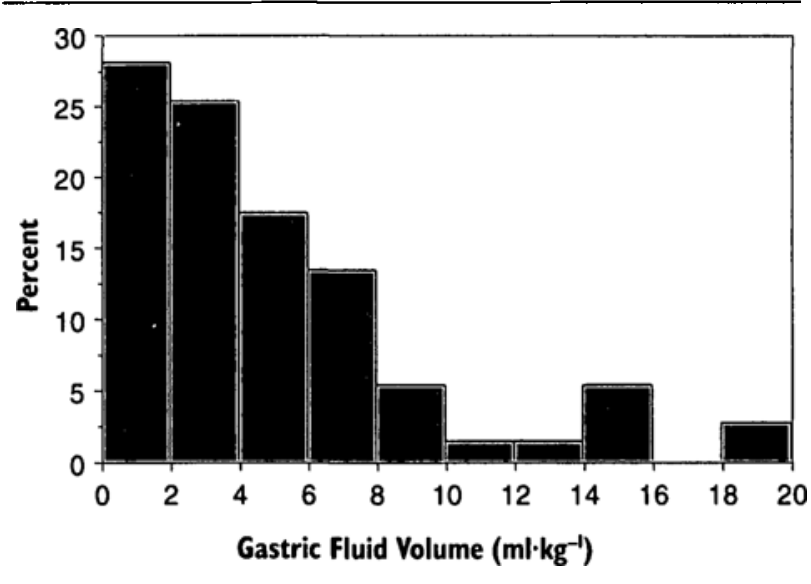

FIGURE 1 This gastric fluid volume frequency distribution for infants with pyloric stenosis represents an $n=72 . G F V_{\text {blind }}$ is the gastric fluid volume recovered by blind aspiration in $\mathrm{ml} \cdot \mathrm{kg}^{-1}$ and represents $96 \pm 7 \%$ of the total gastric fluid volume at the time of surgery.

Based on the endoscopic data for 15 patients, the recovery of $\mathrm{GFV}_{\text {total }}$ with the blind aspiration technique was $96 \pm 7 \%$ (Table II). The residual volume was $\leq 1.0 \mathrm{ml}$ in 14 of these patients, but totaled $7 \mathrm{ml}$ $\left(1.8 \mathrm{ml} \cdot \mathrm{kg}^{-1}\right)$ in one subject. This infant was two weeks of age, weighed $3.9 \mathrm{~kg}$, and had fasted for $>24$ $\mathrm{hr}$. The subject had neither a history of barium administration nor a preoperative nasogastric tube. The blind aspiration technique had removed $35 \mathrm{ml}$ $\left(9.0 \mathrm{ml} \cdot \mathrm{kg}^{-1}\right)$ before induction of anesthesia and subsequent endoscopy.

Ultrasound and/or contrast studies were used in diagnosing pyloric stenosis in our patients. Of the 75 infants, $59(79 \%)$ had their diagnosis confirmed by ultrasound and $17(23 \%)$ had upper gastrointestinal series with barium. Three subjects (4\%) had upper gastrointestinal series with an unknown contrast material. In 13 of the 17 infants who had barium and for whom the time of study was available, $62 \pm 100 \mathrm{hr}$ had elapsed before induction of anesthesia. A history of diagnostic evaluation using barium did not affect $\mathrm{GFV}_{\text {blind }}$ : median $\pm \mathrm{IQR}$ and range of values were $3.4 \pm 4.7(0.6-13.6)$ $\mathrm{ml} \cdot \mathrm{kg}^{-1}$ for infants who had barium versus $3.4 \pm 4.8$ (0.4-19.5) $\mathrm{ml} \cdot \mathrm{kg}^{-1}$ for those who did not $(P=0.59)$.

Only $13 / 75$ (17\%) infants had nasogastric tubes placed preoperatively by either the surgeons or the admitting service. Although intended to reduce gastric fluid volume by intermittent low pressure suction on the ward, the presence of a nasogastric tube did not affect $\mathrm{GFV}_{\text {blind }}$ : median $\mathrm{GFV}_{\text {blind }} \pm \mathrm{IQR}$ and range of values were $2.2 \pm 4.4(0.6-15.4) \mathrm{ml} \cdot \mathrm{kg}^{-1}$ for infants with a nasogastric tube versus $3.6 \pm 4.6(0.4-19.5)$ $\mathrm{ml} \cdot \mathrm{kg}^{-1}$ for those without $(P=0.16)$. 
Finally, despite the theoretical potential for larger GFV with more recent feeding, gastric fluid volume was found to be independent of fasting interval $(P=0.09)$ (Figure 2).

There were only two complications noted during this study. Firstly, the orogastric tube caused minor punctate gastric irritation in most patients (Figure 3.) There was no frank bleeding associated with any of these lesions. More importantly, vomiting on induction occurred once, early in the study, in the only patient for whom the anaesthetist performed blind

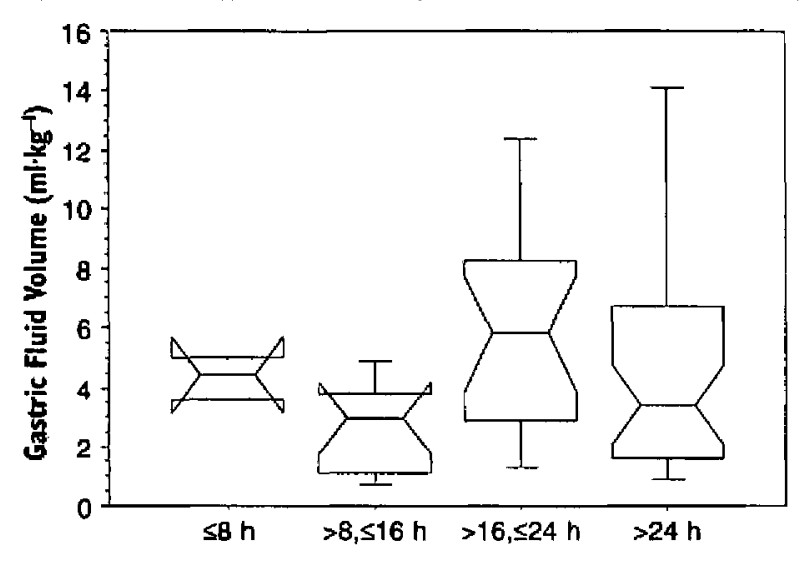

Duration of Fast Prior to Induction of Anesthesia

FIGURE 2 This gastric fluid volume versus fasting interval box plot is derived from an $\mathrm{n}=70$. The five horizontal lines indicate the $10,25,50,75$, and 90 th percentiles. The notches on the box plot represent the $95 \%$ confidence interval about the median. GFV blind is the gastric fluid volume recovered by blind aspiration in $\mathrm{ml} \cdot \mathrm{kg}^{-1}$.

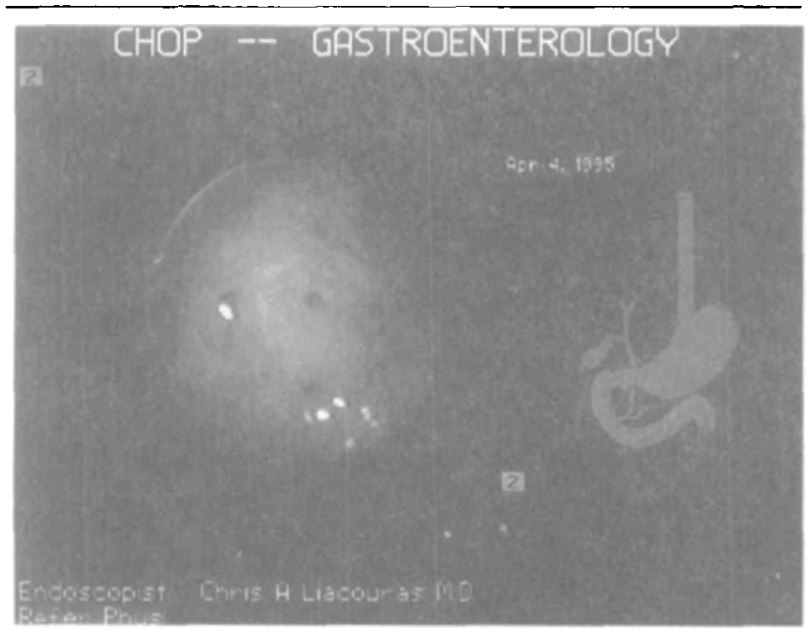

FlǴỦ̉ẻe $\mathfrak{3}$ Ëndoscopic photograph demonstrating typical punctate gastric mucosal irritation caused by the $14 \mathrm{~F}$ multiorificed catheter used for blind aspiration. gastric aspiration after induction. This infant had a diagnosis based on both ultrasound and barium study and underwent induction of anaesthesia using a modified rapid sequence approach after $18 \mathrm{hr}$ fasting. He did not have a preoperative nasogastric tube. Following intubation, $10 \mathrm{ml}\left(2.6 \mathrm{ml} \cdot \mathrm{kg}^{-1}\right.$, not including the vomitus) were evacuated from the stomach using the $14 \mathrm{~F}$ catheter. Despite emesis on induction, there was no laryngospasm or clinical evidence of pulmonary aspiration, and both the operative and postoperative courses were uneventful.

\section{Discussion}

As expected, infants with pyloric stenosis have exceedingly large gastric fluid volumes. With a mean $\mathrm{GFV}_{\text {blind }}$ of $4.8 \pm 4.3 \mathrm{ml} \cdot \mathrm{kg}^{-1}$, they have more than 10 times the $\mathrm{GFV}_{\text {blind }}$ of the fasted healthy paediatric surgical population. We have shown that $95 \%$ of fasted healthy children presenting for elective surgery have GFV $\leq 1.25 \mathrm{ml} \cdot \mathrm{kg}^{-1}$, with an average of $0.40 \pm 0.45 \mathrm{ml} \cdot \mathrm{kg}^{-1}$ and an upper limit of $4.1 \mathrm{ml} \cdot \mathrm{kg}^{-1}{ }^{8}$ In contrast, of our infants with pyloric stenosis, $83 \%$ had $\mathrm{GFV}_{\text {blind }}>1.25$ $\mathrm{ml} \cdot \mathrm{kg}^{-1}$, with one having nearly $20 \mathrm{ml} \cdot \mathrm{kg}^{-1}$.

Although the gastric fluid volumes associated with pyloric stenosis are very large, the blind aspiration technique used successfully evacuated the vast majority of fluid. Unlike our previous study with older infants and children (age six months and over), we did not position the infants into left or right lateral decubitus. In these infants, each less than three months of age, we obtained $96 \pm 7 \%$ of the GFV $\mathrm{Gral}_{\text {tol }}$ in a total of two to three passes of the suction catheter while the infants were in the supine position. This recovery of $\mathrm{GFV}_{\text {toral }}$ is comparable with the $97 \pm 8 \%$ in our previous report. ${ }^{8}$ We attribute the success of the repeated blind aspiration technique in the supine position to the relatively large catheter size in a younger patient population.

The standard deviation about the mean GFV recovery was largely due to the single infant who had a $\mathrm{GFV}_{\text {residual }}$ of $7 \mathrm{ml}\left(1.8 \mathrm{ml} \cdot \mathrm{kg}^{-1}\right)$. This represents only $17 \%$ of the $\mathrm{GFV}_{\text {roral }}$ in this subject, and still supports the effectiveness of the blind aspiration technique in infants with large gastric fluid volumes.

There was some concern that barium used to diagnose pyloric stenosis may both increase the GFV and, because of its viscosity, limit removal of $\mathrm{GFV}_{\text {tlind }}$. Although physicians at our institution routinely use ultrasound alone to confirm the diagnosis of pyloric stenosis, many referring physicians continue to use barium. As a consequence, several infants came to the operating room with residual barium in their stomachs. While gastric barium can be viscous and did seem to obstruct some of the in situ nasogastric tubes, we had 
no problem removing it along with the rest of the gastric fluid using the $14 \mathrm{~F}$ oxygen catheter. Minute barium plaques were commonly noted on endoscopy, but in volumes of $\leq 1 \mathrm{ml}$. This study demonstrated that $\mathrm{GFV}_{\text {blind }}$ was independent of a history of barium administration.

Importantly, the presence of a preoperative nasogastric tube $(\leq 10 \mathrm{~F})$ did not reduce $\mathrm{GFV}_{\text {blind }}$. Traditional preoperative management of infants has included $i v$ fluid and electrolyte replacement, continued npo restriction, and nasogastric tube drainage, the latter two measures in attempt to reduce GFV and decrease episodes of vomiting. At our institution, however, a nasogastric tube is not routinely placed: only $17 \%$ of the infants presenting for pyloromyotomy had a nasogastric tube. For many years it has been our clinical impression that even though an infant had a nasogastric tube, large GFVs would persist to the time of induction of anesthesia for pyloromyotomy. While the median $\mathrm{GFV}_{\text {blind }}$ was slightly lower in infants with preoperative nasogastric tubes than in those without $\left(2.2 \mathrm{ml} \cdot \mathrm{kg}^{-1}\right.$ vs $3.6 \mathrm{ml} \cdot \mathrm{kg}^{-1}$ respectively), this was not statistically significant given our sample size. Moreover, although there may be a true difference between medians which we failed to detect (for these medians, doubling the number of patients would avoid this type II error), this difference would be of no clinical importance to the anaesthetist because of the persistent wide range of GFVs. For example, one subject who had preoperative nasogastric suction presented with a $\mathrm{GFV}_{\text {blind }}$ of $15.4 \mathrm{ml} \cdot \mathrm{kg}^{-1}$, an amount warranting concern at the time of induction of anaesthesia.

Although we evacuated small volumes of GFV via in situ nasogastric tubes and incorporated them into $\mathrm{GFV}_{\text {blind, }}$, we did not record this data separately. While this arrangement maximized the estimate of the GFV at the time of induction of anesthesia, it unfortunately did not allow us to scientifically demonstrate that simple suctioning of small in situ nasogastric tubes was insufficient to effectively recover $\mathrm{GFV}_{\text {total }}$. Throughout this study, however, it remained our clinical impression that only small volumes were removed with the preoperative nasogastric tubes, and subsequent evacuation with the $14 \mathrm{~F}$ multiorificed catheter was required to recover the majority of $\mathrm{GFV}_{\text {total }}$. Based on these observations, our recommendation is to remove in situ nasogastric tubes while applying suction, and then to proceed with the blind aspiration technique described above.

Fasting intervals were not shown to affect the mean $\mathrm{GFV}_{\text {blind }}$ in this patient population (Figure 2.) The data do suggest, however, that the range and dispersion of $\mathrm{GFV}_{\text {blind }}$ dramatically increase with longer fasting intervals. Interestingly, both the largest $\left(19.5 \mathrm{ml} \cdot \mathrm{kg}^{-1}\right)$ and the smallest $\left(0.4 \mathrm{ml} \cdot \mathrm{kg}^{-1}\right) \mathrm{GFV}_{\text {blind }}$ were recorded in infants fasted for $>\mathbf{2 4} \mathrm{hr}$. These findings may relate to the intermittent vomiting associated with the disease: the duration of the fast allows time for variability in vomiting, hence $\mathrm{GFV}_{\text {total }}$, to accrue.

The most serious risk of large GFV is vomiting and subsequent pulmonary aspiration during induction of anesthesia. The single infant whose stomach was not emptied with a $14 \mathrm{~F}$ suction catheter prior to induction and who vomited during induction had $\mathrm{GFV}_{\text {blind }}$ of $2.6 \mathrm{ml} \cdot \mathrm{kg}^{-1}$. Since this figure did not include the vomitus and since this infant did not have an endoscopic evaluation, we are unable to state with certainty his $\mathrm{GFV}_{\text {total }}$ at the time of induction. While there are no data for infants or children, Plourde and Hardy have shown that cats spontaneously regurgitate with GFV ranging from $8-40 \mathrm{ml} \cdot \mathrm{kg}^{-1}$. Adult humans, anaesthetized for gastric resection, spontaneously regurgitate with GFV of $200-2100 \mathrm{ml}\left(3-30 \mathrm{ml} \cdot \mathrm{kg}^{-1}\right.$, assuming an average weight of $70 \mathrm{~kg}$, data which are absent from the article) ${ }^{10}$ Although our study did not address the threshold GFV for spontaneous regurgitation, a large number of our infants did have GFV of $23-8 \mathrm{ml} \cdot \mathrm{kg}^{-1}$, values associated with spontaneous vomiting in the literature, limited as it is. As a final point, it must be remembered that, regardless of the GFV associated with vomiting on induction, difficulty maintaining an airway and pulmonary aspiration of large volumes of acidic fluid are of most concern and do not necessarily follow an emetic episode.

The blind aspiration technique we employed effectively emptied the gastrointestinal tract of all fluid above a single proximal obstruction, the hypertrophic pylorus. We believe this substantially reduces the risk of regurgitation in these infants. After rendering the stomach empty, the anaesthetist may even consider inhalational induction for those without $i v$ access or for those with other issues making awake or rapid sequence induction difficult. For example, in one infant excluded from this study because of a history of Wolff-Parkinson-White syndrome and supraventricular tachycardia, we conducted an inhalational induction following gentle blind aspiration of gastric contents. In this way we avoided the stimulation of an awake or rapid sequence intubation which may have triggered a dysrhythmia.

In summary, infants with pyloric stenosis presenting for surgical repair have exceedingly large gastric fluid volumes: $4.8 \mathrm{ml} \cdot \mathrm{kg}^{-1}$ average $\mathrm{GFV}_{\text {blind }}$. With a recovery of $96 \%$ using our blind aspiration technique, this represents a calculated $\mathrm{GFV}_{\text {total }}$ of $5.0 \mathrm{ml} \cdot \mathrm{kg}^{-1}$, which is more than 10 fold the average amount in an otherwise healthy infant or child fasted for elective surgery. The blind aspiration technique effectively removes $96 \pm 7 \%$ 
of $\mathrm{GFV}_{\text {total }}$. Only one patient had a $\mathrm{GFV}_{\text {residual }}$ of $>1 \mathrm{ml}$ : this was a small volume of $7 \mathrm{ml}\left(1.8 \mathrm{ml} \cdot \mathrm{kg}^{-1}\right)$ and of unlikely clinical importance. A history of barium administration neither increases GFV further nor makes it more difficult to recover GFV using the blind aspiration technique. Importantly, the presence of a preoperative nasogastric tube does not reliably decrease the GFV which remains large regardless of the fasting interval. Although the blind aspiration technique may create punctate gastric mucosa irritation, it is effective in emptying the stomach of infants with pyloric stenosis and should be done prior to the induction of anaesthesia.

\section{Acknowledgments}

Our thanks to Donna Magazine, RN for her skills in coordinating the resources for this study. Also our appreciation to Kathleen A. Harris for her detailed chart review assessing the documentation of the diagnostic radiographic studies and preoperative nasogastric tube placement.

\section{References}

1 Anonymous. The incidence of infantile hypertrophic pyloric stenosis (Editorial). Lancet 1984; 1: 888-9.

2 Spicer $R D$. Infantile hypertrophic pyloric stenosis: a review. Br J Surg 1982; 69: 128-35.

3 Caty $M G$, Azizkhan RG. Acute surgical conditions of the abdomen. Pediatric Annals 1994; 23: 192-201.

4 Hoekelman $R A$. Pyloric stenosis is a pediatrician's diagnosis (Editorial). Pediatric Annals 1994; 23: 181-2.

5 Steven IM, Allen TH, Sweeney DB. Congenital hypertrophic pyloric stenosis. The anaesthetist's view. Anaesth Intensive Care 1973; 1: 544-6.

6 Unal D, Bensoussan A, Rigaut $F$. Anesthésie réanimation pour sténose hypertrophique du pylore. Annalles d'Anesthésiologie Française 1977; 18: 1D-6.

7 Bissonnette B, Sullivan PJ. Pyloric stenosis. Can J Anaesth 1991; 38: 668-76.

8 Cook-Sather SD, Liacouras CA, Previte JP, Markakis $D A$, Schreiner MS. Gastric fluid measurement by blind aspiration in pediatric patients: a gastroscopic evaluation. Can J Anaesth. (In press).

9 Plourde G, Hardy J-F. Aspiration pneumonia: assessing the risk of regurgitation in the cat. Can Anaesth Soc J 1986; 33: 345-8.

10 Tryba $M$, Zenz $M$, Mlasowsky B, Huchzermeyer $H$. Does a stomach tube enhance regurgitation during general anaesthesia? (German) Anaesthetist 1983; 32: 407-9. 